\title{
A Study on the Effect of Detergent Suryagold on the Chronic Toxicity of the Fresh Water Fish Cirrhinus Mrigala
}

\author{
J.Vasanthi ${ }^{1}$, S.Binukumari ${ }^{2}$ And N.Saradhamani ${ }^{3}$ \\ ${ }^{123}$ PG and Research Department of Zoology, Kongunadu Arts and Science college, Coimbatore- \\ 641029Tamilnadu,India
}

\begin{abstract}
To get an idea about the nature of effect of detergent Surya gold on the biochemical aspects of aquatic organisms,fishes belonging to the species Cirrhinus mrigala were exposed to sublethal concentration of $3.5 \mathrm{mg} / \mathrm{L}$ for long term duration.Biochemical characteristics like glycogen,protein and cholesterol were estimated in Liver,Kidney,gills and muscles.The decrease of biochemical constituents from the control were noted.The results are statistically analysed and most values were found to be significant.
\end{abstract}

Keywords: Biochemical analysis, Cirrhinus mrigla, Detergent, Tissues, Surya gold.

\section{Introduction}

Water pollution has become a serious problem throughout the world,it is unfortunate that the rivers are being increasingly used as natural dustbin for discharge of all sorts of community and industrial wastes ([1]).A detergent input in freshwater of India has reached a point of serious concern ([2] ). These detergents enter the system through washings of a variety of objects.

Number of workers have studied the effect of pollutants on physiology and biochemistry of fishes ([3]), ([4]), ([5]), ([6]), ([7]). The effect of detergent Surya gold on the fish has not been carried out.Therefore an attempt has been made to study the possible impact of detergent Surya gold on some biochemical aspect of a freshwater fish Cirrhinus mrigala.

\section{Materials And Methods}

Cirrhinus mrigala is a freshwater carp fish found in India,Pakistan,Bangladesh,Nepal and Burma.It has a slender body,small head blunt snout and thinner lips.Body silvery dark grey along the back.Adult attains a maximum length of $90-100 \mathrm{~cm}$ and a weight of $1.4-2.8 \mathrm{~kg}$.

Bulk of sample of fishes Cirrhinus mrigala ranging in weight from 4-5 gms and measuring 4-6 cm in length were procured from Aliyar fish farm. Fishes were acclimatized to the laboratory conditions for one month in large plastic tank $(200 \mathrm{~L})$.The fishes were fed with adlibitium, rice bran, wheat bran and oil cakes.

Appropriate narrow range of concentration $10-50 \mathrm{mg}$ was used to find the median lethal concentration and the mortality was recorded for every $24 \mathrm{hrs}$ upto $72 \mathrm{hrs}$.It was found as $35 \mathrm{mg}$ for $24 \mathrm{hrs}$ using probit analysis method.([8]).Three groups of fishes were exposed to $3.5 \mathrm{mg}\left(1 / 10^{\text {th }}\right.$ of $24 \mathrm{hrs}$ Lc50 value) concentration of the detergent 'Suryagold' for 24,48 and $72 \mathrm{hrs}$ respectively. Another group was maintained as control.

At the end of the each exposure period, fishes were sacrificed and tissues such as liver,gill,muscle and kidney were dissected and removed,The tissues $(10 \mathrm{mg}$ ) were homogenized in $80 \%$ methanol,centrifuged at 3500 rpm for 15 minutes and the clear supernatant was used for the analysis of different parameters.

Total protein concentration was estimated by the method of ([9]).Quantitative estimation of glycogen in the tissues was done following the method as described by ([10]).Cholesterol was estimated based on enzymatic method using cholesterol esterase,cholesterol oxidase and peroxidase ([11]).

\section{Results And Discussion}

In the present investigation, the effect of a detergent powder suryagold on biochemical nature of glycogen.protein and cholesterol has been studied in the different tissues (Liver,kidney,Gills and muscles ) of the freshwater fish, Cirrhinus mrigala. The results were tabulated (1-3) and statistically analyzed.

In long term duration,glycogen content was found to decrease from control in all tissues in all exposures.Liver tissue was found to contain $10.27,5.57,3.00 \mathrm{mg} / \mathrm{g}$, Kidney tissue was found to contain $20.53,12.30,6.27 \mathrm{mg} / \mathrm{g}$, Gill tissue was found to contain 31.27,25.30,20.40 mg/g, Muscle tissue was found to contain $20.40,11.53,6.27 \mathrm{mg} / \mathrm{g}$ of glycogen in $3.5 \mathrm{mg}$ concentration of detergent Surya gold in 10,20 and 30 days respectively.

The control values were noted as $13.53,29.43,38.30$ and $24.40 \mathrm{mg} / \mathrm{g}$ in Liver, Kidney, Gills and Muscles respectively. The decrease in the glycogen content might have been due to the utilization of reserved glycogen to meet the extra energy demand due to the pollutant stress and also suggests the possible onset of 
glycogenolysis forming free glucose in the exposed tissue ([12]). Decreased glycogen synthesis is also attributed to the inhibition of the enzyme glycogen synthatase which mediates glycogen synthesis ([13]).

Liver recorded 10.27,4.61,1.62 mg/g, Kidney recorded 2.38,2.39,0.36 mg/g, Gills recorded $2.00,1.37,0.05 \mathrm{mg} / \mathrm{g}$, Muscle recorded $6.21,4.28,2.30 \mathrm{mg} / \mathrm{g}$ of protein in $3.5 \mathrm{mg}$ concentration of detergent Surya gold in 10,20 and 30 days exposures. The decreased trend of the protein content in most of the tissues may be due to metabolic utilization of the ketoacids to gluconeogenesis pathway for the synthesis of glucose(Veeriah,2013).Liver recorded 11.53,8.53,4.50 mg/g, Kidney recorded 22.47,11.47,7.40 mg/g,Gills recorded 10.40,8.53,4.17 mg/g, Muscle recorded 18.20,13.40,9.17 mg/g of Cholesterol in $3.5 \mathrm{mg}$ concentration of detergent Surya gold in 10,20 and 30 days exposures.The toxicity stress which suppresses the activity of a number of enzymes responsible for lipid transformation ultimately causing disturbance in lipid metabolism and leads decrease value of cholesterol([14]).The alterations in cholesterol content may be due to its utilization in corticisteroidogenesis and also impairment in the synthesis of cholesterol.Lipids may be mobilized to meet the energy requirement of fish either through oxidation or a process of gradual insaturation of lipid molecules.([15]).

\section{Tables}

Table 1.Changes in the Glycogen content ( $\mathrm{mg} / \mathrm{g}$ ) in the (liver, kidney, gills, Muscles) of Cirrhinus mrigala exposed to $3.5 \mathrm{mg} / \mathrm{L}$ of detergent Surya gold on Long term duration .

\begin{tabular}{|c|c|c|c|c|}
\hline \multirow{2}{*}{$\begin{array}{c}\text { Tissues } \\
\mathrm{mg} / \mathrm{g}\end{array}$} & & \multicolumn{3}{|c|}{ Exposure Periods } \\
\hline & & 10 days & 20 days & 30 days \\
\hline Liver & $\begin{array}{l}\text { Control } \\
\text { Experimental } \\
\text { 't' value } \\
\% \text { change }\end{array}$ & $\begin{array}{l}13.53 \pm 0.05 \\
10.27 \pm 0.05 * * * \\
7.37 \\
-24.09\end{array}$ & $\begin{array}{l}13.50 \pm 0.05 \\
5.57 \pm 0.05 * * * \\
2.10 \\
-58.74\end{array}$ & $\begin{array}{l}13.56 \pm 0.05 \\
03.00 \pm 0.05 * * * \\
7.23 \\
-76.40\end{array}$ \\
\hline Kidney & $\begin{array}{l}\text { Control } \\
\text { Experimental } \\
\text { 't' value } \\
\% \text { change }\end{array}$ & $\begin{array}{l}29.43 \pm 0.05 \\
20.53 \pm 0.05 * * * \\
1.32 \\
-30.24\end{array}$ & $\begin{array}{l}29.46 \pm 0.05 \\
12.30 \pm 0.05 * * * \\
9.61 \\
-58.24\end{array}$ & $\begin{array}{l}29.40 \pm 0.05 \\
6.27 \pm 0.05 * * * \\
2.91 \\
-78.67\end{array}$ \\
\hline Gills & $\begin{array}{l}\text { Control } \\
\text { Experimental } \\
\text { 't' value } \\
\% \text { change }\end{array}$ & $\begin{array}{l}38.30 \pm 0.05 \\
31.27 \pm 0.05 * * * \\
3.41 \\
-18.35\end{array}$ & $\begin{array}{l}38.34 \pm 0.05 \\
25.30 \pm 0.05^{* * *} \\
2.88 \\
-34.01\end{array}$ & $\begin{array}{l}38.30 \pm 0.05 \\
20.40 \pm 0.05 * * * \\
8.11 \\
-46.73\end{array}$ \\
\hline Muscle & $\begin{array}{l}\text { Control } \\
\text { Experimental } \\
\text { 't' value } \\
\% \text { change }\end{array}$ & $\begin{array}{l}24.40 \pm 0.05 \\
20.40 \pm 0.05 * * * \\
3.25 \\
-16.39\end{array}$ & $\begin{array}{l}24.40 \pm 0.05 \\
11.53 \pm 0.05 * * * \\
3.03 \\
-52.74\end{array}$ & $\begin{array}{l}24.42 \pm 0.05 \\
6.27 \pm 0.05 * * * \\
7.67 \\
-74.32\end{array}$ \\
\hline
\end{tabular}

Results are mean $( \pm \mathrm{SD})$ of observations

$\%=$ percentage decrease over control

$*$ = Significant at 0.05 level $* *=$ Significant at 0.01 level $* * *=$ Significant at 0.001 level

NS $=$ Non Significant

Table 2.Changes in the Protein content ( $\mathrm{mg} / \mathrm{g}$ ) in the (liver, kidney, gills, Muscles) of

Cirrhinus mrigala exposed to $3.5 \mathrm{mg} / \mathrm{L}$ of detergent Surya gold on Long term duration .

\begin{tabular}{|c|l|l|l|l|}
\hline \multirow{2}{*}{$\begin{array}{c}\text { Tissues } \\
\mathbf{m g} / \mathbf{g}\end{array}$} & \multicolumn{3}{|c|}{ Exposure Periods } \\
\cline { 3 - 5 } & & $\mathbf{1 0}$ days & $\mathbf{2 0}$ days & $\mathbf{3 0}$ days \\
\hline \multirow{3}{*}{ Liver } & Control & $34.35 \pm 0.05$ & $34.30 \pm 0.05$ & $34.0 \pm 0.05$ \\
& Experimental & $10.27 \pm 0.05$ & $4.61 \pm 0.05$ & $1.62 \pm 0.05$ \\
& 't' value & 2.47 & 1.07 & 7.58 \\
& \% change & -70.10 & -86.55 & -95.23 \\
\hline \multirow{3}{*}{ Kidney } & Control & $3.41 \pm 0.05$ & $3.46 \pm 0.05$ & $3.40 \pm 0.05$ \\
& Experimental & $2.38 \pm 0.05$ & $2.39 \pm 0.05$ & $0.36 \pm 0.05$ \\
& 't' value & 7.32 & 6.29 & 9.74 \\
& \% change & -30.20 & -30.92 & -89.41 \\
\hline \multirow{3}{*}{ Gills } & Control & $4.32 \pm 0.05$ & $4.3 \pm 0.05$ & $4.37 \pm 0.05$ \\
& Experimental & $2.0 \pm 0.05$ & $1.37 \pm 0.05$ & $0.05 \pm 0.05$ \\
& 't' value & 2.52 & 2.65 & 6.01 \\
& \% change & -53.70 & -68.13 & -98.85 \\
\hline \multirow{3}{*}{ Muscle } & Control & $8.40 \pm 0.05$ & $8.49 \pm 0.05$ & $8.40 \pm 0.05$ \\
& Experimental & $6.21 \pm 0.05$ & $4.28 \pm 0.05$ & $2.30 \pm 0.05$ \\
& 't' value & 2.52 & 2.65 & 6.01 \\
& \% change & -26.42 & -49.58 & -72.61 \\
\hline
\end{tabular}

Results are mean $( \pm$ SD) of observations

$\%=$ percentage decrease over control

$*$ = Significant at 0.05 level $* *=$ Significant at 0.01 level $* * *=$ Significant at 0.001 level

NS $=$ Non Significant 
Table 3.Changes in the Cholesterol content (mg/g) in the (liver, kidney, gills, Muscles) of Cirrhinus mrigala exposed to $3.5 \mathrm{mg} / \mathrm{L}$ of detergent Surya gold on Long term duration .

\begin{tabular}{|c|c|c|c|c|}
\hline \multirow{2}{*}{$\begin{array}{c}\text { Tissues } \\
\text { mg/g }\end{array}$} & & \multicolumn{3}{|c|}{ Exposure Periods } \\
\hline & & 10 days & 20 days & 30 days \\
\hline Liver & $\begin{array}{l}\text { Control } \\
\text { Experimental } \\
\text { 't' value } \\
\% \text { change }\end{array}$ & $\begin{array}{l}26.20 \pm 0.05 \\
11.53 \pm 0.05 * * * \\
1.79 \\
-55.99\end{array}$ & $\begin{array}{l}26.00 \pm 0.05 \\
8.53 \pm 0.05 * * * \\
8.94 \\
-67.19\end{array}$ & $\begin{array}{l}26.10 \pm 0.05 \\
4.50 \pm 0.05 * * * \\
3.82 \\
-82.75\end{array}$ \\
\hline Kidney & $\begin{array}{l}\text { Control } \\
\text { Experimental } \\
\text { 't' value } \\
\% \text { change }\end{array}$ & $\begin{array}{l}45.50 \pm 0.05 \\
22.47 \pm 0.05 * * * \\
4.46 \\
-50.61\end{array}$ & $\begin{array}{l}45.55 \pm 0.05 \\
11.47 \pm 0.05 * * * \\
6.17 \\
-74.81\end{array}$ & $\begin{array}{l}45.50 \pm 0.05 \\
7.40 \pm 0.05^{* * *} \\
3.95 \\
-83.73\end{array}$ \\
\hline Gills & $\begin{array}{l}\text { Control } \\
\text { Experimental } \\
\text { 't' value } \\
\% \text { change } \\
\end{array}$ & $\begin{array}{l}22.47 \pm 0.05 \\
10.40 \pm 0.05 * * * \\
3.92 \\
-53.71 \\
\end{array}$ & $\begin{array}{l}22.40 \pm 0.05 \\
8.53 \pm 0.05 * * * \\
2.25 \\
-61.91 \\
\end{array}$ & $\begin{array}{l}22.42 \pm 0.05 \\
4.17 \pm 0.05 * * * \\
7.51 \\
-81.40 \\
\end{array}$ \\
\hline Muscle & $\begin{array}{l}\text { Control } \\
\text { Experimental } \\
\text { 't' value } \\
\% \text { change }\end{array}$ & $\begin{array}{l}36.20 \pm 0.05 \\
18.20 \pm 0.05 * * * \\
7.93 \\
-49.72\end{array}$ & $\begin{array}{l}36.00 \pm 0.05 \\
13.40 \pm 0.05 * * * \\
3.19 \\
-62.77\end{array}$ & $\begin{array}{l}36.22 \pm 0.05 \\
9.17 \pm 0.05 * * * \\
1.55 \\
-74.68\end{array}$ \\
\hline
\end{tabular}

Results are mean $( \pm \mathrm{SD})$ of observations

$\%=$ percentage decrease over control

$*$ = Significant at 0.05 level $* *=$ Significant at 0.01 level $* * *=$ Significant at 0.001 level

NS $=$ Non Significant

\section{Conclusion}

Glycogen showed maximum decrease as $(-78.67 \%)$ in kidney during 30 days exposure and minimum as $(-16.39 \%)$ in muscles during 10 days exposure. Protein showed maximum decrease as (-98.85) in gills during 30 days exposure and minimum as $(-26.42 \%)$ in muscles during 10 days exposure. Cholesterol showed maximum percentage decrease as $(-83.73 \%)$ in kidney during 30 days exposure and minimum as $(-49.72 \%)$ in muscles during 10 days exposures It can be concluded that the toxicity of the detergent may lead to severe effect of aquatic organisms.

\section{Acknowledgements}

The authors are grateful to Department of zoology, Kongunadu Arts and Science College for guiding and providing necessary help for conducting this research studies.

\section{References}

[1] Aravindkumar, Studies on Pollution in river mayurakshi in south bihar,India. J.Environment.Poll.2(1),1995, 21-26.

[2] B.Mukherjee, A.SinhaRoy, S.Manty, P.Chatterjee and P. Sinta, The influx of detergents and their effect on the oxygen and carbon budgets in freshwater systems. J.Ecobiol. 4(1),1992,45-53.

[3] P.Amudha, G. Sangeetha, and S. Mahalingam, Diary effluent induced alterations in the protein, carbohydrate and lipid metabolism of a freshwater teleost fish Oreochromis mossambicus.Poll.res.21 (1),2002, 51-53.

[4] V.D.Sonawane, A.H. Pawar and M.T.Hyalij, Nature Environment and pollution technology. Vol.3.No.2, 2004, PP. 239-242.

[5] Pathak Priti, K. Srivastava Dhanajay and K.Srivastava Arun, Effects of an anionic detergent "Nirma" on blood and tissue biochemistry of a freshwater catfish, Heteropneustes fossilis (Bloch). Journal of Ecophysiology \& Occupational Health. Volume : 6, Issue : 3 \& 4,2006.

[6] K.Shanthi, Kiran Joseph and M.Manimegalai, Studies on biochemical changes in the liver and kidney due to sterling biotech limited industry effluent in freshwater fish, Labeo rohita (Hamilton).Indian J.Environ \&Ecoplan 16(1),2009, 145-150.

[7] K.Kannan, G.Rajasekaran, and R.Raveen, Heavy metal Mercuric chloride induced biochemical changes in the freshwater catfish Mystus Vittatus. J.Ecotoxicol.Environ. Monit.20(1),2010,97-99.

[8] D.J.Finney, Probit analysis, $3^{\text {rd }}$ edition, (London : Cambridge University press), 1971, Pg.20.

[9] O.H.Lowry, N.J. Rose Brough, A.L. Farr and R.J. Randall. Protein measurements with the folin phenol reagent. J.Biol.chem. 193,1951,265275.

[10] A.Kemp, and A.J.M. Kits Vaheijnigen, A calorimetric micro-method for the determination of glycogen in tissues. J.Biochem.56(4),1945,646-648.

[11] W.Richmond, Preparation and properties of a cholesterol oxidase from Nocardia sp. and its application to the enzymatic assay of total cholesterol in serum.Clin.Chem. 19,1973,1350-1356.

[12] V.Sreenivasa, Studies on the effect of pesticide on cardiac and body muscles of freshwater gobiid fish Glossogobius giuris (Ham). Ph.D.thesis, Bangalore University,India,2002.

[13] K.Veeriah,P.Srinivas Rao,A.Symyuktha Rani and H. Dhilleswarao, Changes in Biochemical parameters of Fresh water fish Labeo rohita exposed to Lethal and Sub-lethal concentrations of Indoxacarb,Int.J.Bioassays, 02(10),2013,1382-1387.

[14] R.M.Ganeshwade, Effect of Dimethoate on the level of cholesterol in freshwater Puntius ticto (Ham),Science Research Reporter, 2(1), 2012, 26-29.

[15] D.Shelke Abay, Comparative study of cholesterol Alterations in a Fresh water teleost fish,Amblypharyngodon Mola exposure to Heavy metals, The Bioscan,J.of Life Sciences 8(3),2013,1001-1004. 